Martyna Pilas

https://doi.org.10.26881/ae.2020.17.08

ORCID: 0000-0003-0401-2677

Uniwersytet Gdański

\title{
Tripartite school conflicts and non-consensual democracy. An attempt of autoethnographic analysis
}

\begin{abstract}
About autoetnography
Qualitative research, granting the researcher a personal right to engage in the research process, create the perfect conditions to come into being, to discover, and to change. One of the areas where it can reveal is the researcher's development understood as discovering a new quality through self-understanding and self-retelling (Denzin, Lincoln 2005; Ciechowska, Szymańska 2017).

Autoethnography (AE) as "a specific type of activity on the border of science and art, science and therapy, science and the social philosophy of dialogue" 1 (Kafar 2010: 335) gives the opportunity to collect interesting research material by analyzing oneself and other social actors. It allows to study phenomena that are difficult to access by other qualitative and quantitative methods. Good autoethnography reveals hidden dimensions of social life, making it possible to understand the intricate mechanisms that govern the world of organizations (Zawadzki 2015).

The development of AE in the social sciences over the past four decades has brought a wide variety of approaches and applications and its growing popularity can be seen in social science magazines and books, including methodological manuals (Hayano 1979; Van Maanen 1988; Denzin 1989, 1997, 2018; Ellis 2004, 2009; Ellis, Bochner 2000; Reed-Danahay 1997; Holman Jones 2005; Doloriert, Sambrook 2009, 2011; Sambrook, Hermann 2018; Anderson 2014; Chang 2008; Maréchal 2010; Richardson 2000, 2007; Sparkes 2000). The process can be also noticeable and recognizable among Polish researchers (Kafar 2010; Kacperczyk 2014a, 2014b;
\end{abstract}

\footnotetext{
${ }^{1}$ Translated by Pilas.
} 
Bielecka-Prus 2012, 2014; Kamińska 2014; Kępa 2012, 2014; Polczyk 2012; Jakubowska 2017; Zawadzki 2015; Ciechowska, Szymańska 2017; Pilas 2020a, 2020b).

Research practices that fall under the term "autoethnography" are hardly a uniform method. There are three levels of autoethnography used: 1) data production, the technique of receiving information; 2) solving research problems, the method or research strategy; 3) the epistemological level, the new paradigm of social research (Ciechowska, Szymańska 2017; Kacperczyk 2014a).

Autoethnography as one of the research methods strongly refers to the perspective of a participant in social life. This is due to the subject of interest of these sciences - related to the phenomena of human consciousness. The method can be divided into two types: emotional and analytical.

Carolyn Ellis proposes introspection and narrative inquiry as methods based on interpretative materials created by the researcher himself and by others extremely useful for understanding the vivid experience of emotions (Ellis 2004).

In autoethnography, unlike in ethnography, the character of the researcher performs a key function. This means that an additional element of the autoethnographic description is a critical look at your own experience and explaining it through references to the cultural context in which the experience occurred.

\section{Autoetnographic inclusion 1}

September 20, 2018

Each end of the school year is an obvious moment to summarize my teacher's professional achievements and failures. When successes inspire me and my sense of fulfillment, prompting a decision to continue, failures cause frustration, which in turn lead to a feeling of powerlessness, resignation or downplaying the problem, or vice versa, looking for solutions and motivation to change. It was no different at the end of last school year. I considered the greatest professional failure to be helpless in the face of increasing aggression and violence against myself and teachers in the behavior of students, on the one hand, resignation and withdrawal from oneself, lack of trust and hope in solving problems on the other. However, the most frustrating for me was the number of conflicts, the failure to resolve, omit or simply unaware of them led to a large number of students changing schools, even for the final year of education (grade 8). Making decisions to transfer a child to another facility for several years

I considered to be my direct or indirect professional failure and finding out its reasons was my main task for each subsequent school year. While searching for a solution and after analyzing my own observations, I came across a theory according to which the main reason for a child's frustration is their lack of belonging and importance in a given school community, bad communication resulting from the disappearance of such virtues as respect and empathy. Based on the theory of mutual respect and on the assumptions of individual psychology of Austrian psychiatrists, Alfred Adler and Rudolf Dreikurs, the American psychologist Jane Nelsen created a classic educational method, which she called Positive Discipline.

I have been working as a teacher for 10 years now and this theory opened my eyes. I was looking for it in my first 5 years of teaching adults at a non-public school, then when I changed it into a public primary school very close to my house and where I enrolled my daughter. Since then I have had many observations and concerns about school conflicts according to my double role in the school life, a parent and a teacher. 
On the other hand, there is a more analytical approach. Leon Anderson pointed out five key features: 1) the researcher belongs to the environment he researches, occupying the position of its complete member; 2 ) undertakes analytical reflection throughout the entire data collection and development process; 3 ) reveals his self in the narratives he created, but he does not stop there; 4) also undertakes a dialogue with informers belonging to the studied environment, giving the chance for a narrative to resound other than your own; 5) puts great emphasis on theoretical analysis, which links the researcher's conclusions to a wider field of theoretical solutions in a given problem area, which ultimately allows the incorporation of the research conclusions into the circulation of scientific knowledge (Anderson 2014; Zawadzki 2015). Anderson's theory is related to an analytical autoetnography considered by some to be too far away from autoetnography itself (Denzin 2003).

In my research project I decided to combine those two approaches: emotional in narratives and observation sheet's section - emotions and analytical in creating the conflict criteria and the analysis of school conflict observation sheets.

Mark Neumann sees the main function of autoethnography in the fact that "autoethnographic texts democratize the representative sphere of culture by placing the individual's experience in tension against the dominant expressions of discursive power" (Neumann 1996: 189 - citation after Kacperczyk 2014a: 52).

In this sense, autoethnography becomes a democratic activity that fights to create a space for dialogue and debate that is the leaven of social change and allows voting for those who are marginalized themselves. The most important advantage of autoetnography is its emancipatory and empathetic character, its overarching goal is to create a space for dialogue and debate that initiate and shape social change (Neumann 1996; Holman, Jones 2009; Kacperczyk 2014a; Zawadzki 2015).

One of now gaining popularity versions of autoetnography is the one conducted by organization researchers (OAE). Autoethnography allows for in-depth insight into the context of the studied organization and understanding the activities of other people involved in organizational processes. The subject of research are often organizational pathologies such as mobbing, exploitation or sexual violence in the workplace (Zawadzki 2015; Doloriert, Sambrook 2009, 2011; Sambrook, Hermann 2018).

Autoethnography as a research practice is now often used by researchers in the field of sociology of sport and the sociology of the body (embodiment). According to Jacquelyn Allen-Collinson, who writes about the "auto-ethnographic turn" (see also Kafar 2010), which is visible in the area of physical activity and sport. Researchers use autoethnography to recreate the process of recovering from an injury, struggling with pain, the practice of controlling the sports body, as well as other everyday experiences related to sport (Jakubowska 2017; Allen-Collinson, Hockey 2001; Allen-Collinson 2011). 


\section{The orientation on the positive meaning of disagreement}

The school in my article is perceived as a place of conflict which is an unobvious expression of democratic dissent and a difficult way of achieving commonality, which is a condition of democracy. The conflict is an indispensable social element and the basis of relations of subjective character (Rancière 1999; Coser 2009).

Lewis A. Coser expressed a belief in the functionality of the conflict, which if not too intense and rapidly increases the adaptability of a society. When real and constructive, it leads to strengthening of the system, if destructive - to its weakening and even destruction. Currently, the issue of conflict culture is widely discussed in Poland in the field of economics and sociology of organizations.

Pierre Bourdieu exposed the symbolism and arbitrariness as a tool of dominion and socialization aimed at preserving and reproducing culture. Bourdieu also clarified the concept of habitus, which by definition are imposed initially by the house and, for example, by the school, and can compete with each other (Bourdieu, Passeron 1990). On this basis, I have found conflict to be an indispensable element of school life and the educational process. John Dewey, in turn, inseparably linked school with democracy. He considered the school space as an example of a small society in which a student acquires civic competence. The basic socio-pedagogical assumption on which I based my research is also the need for dialogue in the relationships of all actors of school life. Maria Mendel, states that "commonality is an expression of the manifestation of dialogue, which is a key form of democratic existence" (Mendel 2017: 285) The building of the space of the "common peace" occurs in the process of conflict and dialogue demanding equality in treatment. We cannot think about dialogue when the basic principles of democracy, namely equality, justice, dignity and freedom are not respected.

The principles of equality between adults and adolescents have been presented by Mendel. She wrote: "The adults and adolescents are equal in terms of autonomy, each of them retains their rights and obligations - different for the adult, different for the child; they are equal in terms of their cooperation - they jointly define and accept its purpose, course and results" (Mendel 2000).

This cooperation the author calls the Partnership that is a relationship in which entities self-realize in cooperation, treating their own rights and the fact of cooperation as a value (Mendel 2000).

\section{Autoetnographic inclusion 2}

September 28, 2018

Every year we organize the European Day of Foreign Languages. Each class prepares costumes, food and posters related to the selected country. During the presentation, when the students line up at their tables in the hall, there is always a lot of noise, it is cramped and intense. 
This year, I coordinated this event myself, because my friend Maria fell ill. For the presentation of the nationalities, I decided that only class representatives of 3 people and those who changed clothes or prepared the dish will perform. This was also the case in class $4 \mathrm{a}$ where my daughter is. The event was a success.

The next day, just by 8 am, when I entered the school, I was accosted by Wojtek's ${ }^{2}$ father from grade $4 \mathrm{a}$. He was very nervous. His eyes glowed with anger. I asked him outside the school where he said:

- My son was very badly and unfairly treated yesterday. Why didn't you let him do the country presentation? After all, he made pancakes. He never again wants to participate in any ceremony, if he is treated like that, when some children in grade $4 \mathrm{a}$ are favored

It stunned me. I completely didn’t know anything about Wojtek making pancakes. I announced this to the outraged man. I apologized. I remembered that Magda, the class teacher of $4 \mathrm{a}$, was not there yesterday. Perhaps that is why in all the confusion I did not notice that Wojtek was also involved in the preparation will take.

I felt terrible attacked and shocked. On the one hand, I felt stupid and sorry that Wojtek was treated badly and, as the main organizer of the competition and mother of Wojtek's class friend, I felt responsible for the failure. On the other hand, I felt hurt because I tried very hard and did't receive any support in organizing the ceremony. As a teacher and a parent I felt discouraged.

\section{The importance of the student's point of view from paidocentric perspective}

Progressive Education is more than a century old but it is still a revolution: breaking with the authoritarianism of the teacher, freeing the education process from the dogmas of the adult world, allowing the formation of uncontaminated social relations and conflict resolution skills for the benefit of the environment and oneself (Śliwerski 2007).

A game of who has power, and since adults have power in this case, children have no chance of changing these rights or learning about them. How to teach children about their rights (established or postulated) so that they do not release degenerate distrust and resentment towards adults? How not to strengthen the natural tendency of young people to undermine the authority of adults? The emancipation of children is, in fact, the basic condition for the emancipation of parents. Both sides need each other as trustworthy partners.

\section{Autoetnographic inclusion 3}

\section{March 21, 2019}

One of the $5^{\text {th }}$ grade students, Michał did not want to listen to the spring celebration prepared by the younger children. He was complaining, interrupting, acting impolitely. He said: "I don't care about the school rules". I asked him to come with me and talk. His attitude intrigued me.

\footnotetext{
${ }^{2}$ All students and teachers' names in autoetnographical inclusions are changed.
} 
We sat down on the chairs in a smaller room, and I said that his behavior was arrogant. I asked why he was acting this way. The student was very irritated, he replied reproachfully and reluctantly without meeting my eyes:

- All you teachers are the same! You don't listen to us, you just shout!

I asked:

- Now I am talking to you. I'm not shouting. Am I the same as all teachers?

- No. You are fine - answered Michał.

- Then why do you think all teachers are bad?

- Because the lady from PE treats us like that. We have nothing to say. We must always comply. No discussion. I don't want to go to that school - answered Peter.

- I understand. If I were you, I wouldn't want to go to school either. I am not surprised that you are nervous, after all, this is your school, and you have the right to express your opinion about it.

- But my parents don't think so. They say to keep quiet, or the teachers will be causing me and my sister problems.

- That does not sound appealing. Nevertheless, I am very happy with your bravery and wisdom. But disrupting the school celebration is not the best way to express your opinion about the mistreatment of students by some teachers.

- It just seems to come from helplessness - he answered.

- How else could you point out to unfair treatment? Think about a solution.

- Maybe I could talk to other students, and then to the class teacher. We can write a letter to the principal.

- Good start. Let's go back to the celebration.

Our conversation lasted 10 minutes. We returned to the sports hall where the spring celebration was ending. Michał quietly sat down next to his friends. It felt like his attitude had changed.

The basis of my approach consistent with the assumptions of non-consensual democracy is such a goal of resolving the conflict situation so each party turns out to be a winner not only from a moral or educational point of view, but also in the field of personal feelings, beliefs and a sense of integrity.

Leszek Koczanowicz called the manner of social arrangement and dialogue, which he is capable of but does not have to lead to an agreement, or consensus, a non-consensual democracy. It is a policy of dialogue in social action. The political scientist, basing on the literary concept of Mikhail Bachtin's polyphony, refers to social polyphony, repeats that dialogue is subjective. The word is always an externalized, specific author. Koczanowicz states: Thus, dialogue relations are always subjective and as such transfer to the sphere of dialogue all the tension that may arise between various entities. Therefore, dialogue does not have to, and generally does not lead to consensus, it must lead, if undertaken, to better understanding (Koczanowicz 2015).

\section{Autoetnographic inclusion 4}

January 23, 2019

The bell rang for the lesson. I left the staff room and headed towards the library, where Grade 8 , loud as usual, was waiting for me. The headmistress was following me. I pushed to open the door when something suddenly flew towards me. I almost got hit in the face. It was a large paper tube 
for artwork. I was shocked and scared. The students started laughing, which upset me very much. The headmistress walked in behind me and after finding out who had thrown the item and that it was just a form of fun that got out of hand, she left the library. I, on the other hand, could not cool down. I got into a riot with some of the students, especially with the most outspoken student, Kasia. I never got along very well with Grade 8. I found most of the students to be arrogant and spoiled kids. But this time the scoop has changed. I was expecting words of apology. Emilia and Krzyś, the boy from whose hands the tube flew towards me, joined the argument about this attack on me. The level of nervousness was so high that I was unable to teach. After a while, the class 8 teacher, Karolina, entered the room. She listened to our quarrel for a while, then, at my request, she joined the conversation, which she tried to soften. Finally, the lesson was over, but not my hurt and nervousness. I decided to add negative comments to e-register and call Kasia and Krzyśs parents to school. The next morning at 7.30 a meeting with the parents took place. I presented calmly what happened in yesterday's English lesson. I told the event from my own point of view. Then I asked to present the incident from the parents' point of view, what they heard from their children. Kasia's dad stepped in right away. He said that the children were treated unfairly by me and that it was all my fault. I felt like someone slapped me in the face. The other parents joined this position, attacking me and my point of view. They said that I was not attacked by the students and that I had no right to claim an apology. Our nervous conversation was interrupted by the bell for the lesson, and the meeting moved to the office of the pedagogue who joined the conversation. Her presence and sense of humor softened the atmosphere a bit. Nevertheless, I still felt terrible. The culminating moment came when Kasia's father said that I was a teacher and that I should know better than him how to raise his daughter, it is the teachers' fault that his daughter is unbearable (he said "All you teachers are the same!"). After these words, I burst into tears. I was ashamed of it, but I couldn't control myself. I felt helpless and guilty and hurt. Despite the unfavorable atmosphere, the parents agreed to talk to their children again, and I decided to soften the form of negative comment in the e-register. The next day the 8 th grade students apologized to me for their behavior.

\section{The analysis of observation sheets}

Based on the observation of the effectiveness of the above tools in the spirit of the interpretative paradigm and in line with critical pedagogy, I conducted a case study of a school conflict. I used ethnographic and autoethnographic instruments to study the nature and specificity of the case due to my deep involvement in the studied environment. I kept conflict observation sheets, a researcher's journal and analyzed the documentation. For the purposes of this text, I have decided to discuss four cases of conflict situations in which I was a party as a conflicted person in the period from September 2018 to March 2019.

When preparing the observation sheet, I selected the appropriate criteria. I adapted and expanded the proposed elements: 1) duration; 2) stages; 3) source; 4) dynamics; 5) form of disclosure; 6) post-conflict situations and effects; 7) accompanying emotions (Olubiński 2015; Wajszczyk 2015).

All the analyzed school conflicts (disagreements) are presented in the autoetnografic inclusions as follows: conflict no. 1 - inclusion 2, conflict no. 2 and 3 inclusion 4 , conflict 4 - inclusion 3. 
Disagreement no. 1 took place between me and a parent, no. 2 my and group of parents (school pedagogue - mediator), no. 3 me as a teacher and group of students (class teacher as a mediator) and no. 4 me and a pupil. In each case, I tried to identify the conflict's source. I determined the reasons for the disagreements in order: 1) uneven distribution of privileges, positions, a sense of unfair treatment of students by the teacher; 2) different views on values considered important, generalization in the perception of the teacher's reaction and role; 3 ) contradiction of individual assessments and opinions and views on values considered important (e.g. safety and respect), competition for power between students and teacher; 4) uneven distribution of privileges and positions, confrontation of individual grades and opinions, communication difficulties (Wajszczyk 2015). As you can see in most cases it was difficult to identify one specific source. Each conflict situation was a complex, often long-developing phenomenon that increased until the climax, which was usually a confrontation. In terms of form, the analyzed conflicts can be summarized as follows: no. 1: attack, violent quarrel between the parent and teacher regarding unfair but unconscious treatment of the student by the teacher, no. 2: stormy discussion between the teacher and the group of parents, accusing the teacher of improper performance of his pedagogical and educational duties and abuse of the students, no. 3: verbal scuffles between teacher and students, boycott of lessons by students, an attempt to bring accountability to students whose fun has become out of control, no. 4: : student's withdrawal from social relations, boycott in complying with school rules, persuading the student to discuss and reveal the problem. The conflicts were characterized by different dynamics, levels of intensity and violence, but usually they revealed by sudden confrontations (case no. 1,2 and 4), then they took the form of an attempt to calm the situation, clarify the matter, express understanding of the problem and draw conclusions (no. 1, 3, 4). During the discussion the emotions appeared: screaming, arguing, crying, also on the adult side. The conflicts were accompanied by the following feelings: surprise, anger, disbelief, shame, misunderstanding, disrespect, confusion, embarrassment, harm, sadness, powerlessness. In the case of conflicts in which a mediator was actively and impartially involved, we can speak of lower violence and emotional level (no. 2 and 3). However, neither the violence of the conflicts nor the emotions they evoked had an impact on the most important common feature I observed: they gave me the opportunity to express the opinions. Although sometimes the points of view were completely contradictory, e.g., in case no. 3, the appropriate resolution of the conflict resulted in their occurrence and reverberation. Hiding or disregarding would not have a similar effect. 


\section{Conclusions}

In this autoethnographic study I tried to prove that school conflicts should not frighten or be avoided when they arise. One might object that this way of understanding methods of dealing with conflicts that do not lead to a specific solution and agreement is pointless and ineffective. In this sense, the phrase "conflict resolution" can lose power in favor of managing or playing it out. However, it is precisely giving each participant of a conflict situation the right to speak, the possibility of explaining themselves, showing mutual understanding and the possibility of jointly agreeing on solutions that are the most effective. The basis of my approach in line with the assumptions of non-consensual democracy is the goal of playing out a conflict situation in such a way that each side wins, not only from a moral or educational point of view, but also in terms of personal feelings, beliefs and a sense of integrity. The second objection I may encounter is perhaps an overly idealistic and trusting approach to interpersonal relations. How can we eliminate fraud, deception, and self-interest? I believe that only honesty and abandonment of fear-based relationships can make lying and abuse unprofitable, will not lead to the satisfaction of the most important social needs, which include a sense of importance and belonging, and fair and equal treatment. The last counter-argument I will probably come across, especially among practitioners, is the belief that giving up the superior-subordinate teacher-student relationship will negatively affect the former, lose respect and authority, and lose control. On the contrary, the teacher will demonstrate the most professional side when he uses his competences not in imposing his own beliefs and disciplining, but in the ability to see the advantages in a thoughtful and creative approach to conflict.

All 4 conflicts were strongly influenced by students and parents' needs. Conflicts no. 2 and 4 were greatly rooted in the lack of trust in adults in parents and the teachers. I had a strong impression that all 4 conflicts were the effects of many previous unfair or unexplained situations. The parents in conflict no. 2 said accusingly: "All you teachers are the same!". The students in fourth case argued: "You teachers don't listen to us, you just shout!".

School conflict could be resolved more effectively if we include the subjectivity and even the authority of students as the third party in the process of democratic dialogue. Conducting the research I wanted to prove that teacher can gain a specific competence of resolving conflicts listening to students and parents as well as to him/ herself in autoetnographic manner. This is certainly not the easiest task, it requires more effort and time, but from the non-consensual democracy point of view, it is the most legitimate solution. This approach is a vision of a "decent, sufficiently perfect society, democracy that must come" (Włodarczyk 2017: 29) in a school environment that seeks to maintain a democratic character. 


\section{Literature}

Allen-Collinson J., 2011, Feminist phenomenology and the woman in the running body, Sport, Ethics \& Philosophy, 5(3).

Allen-Collinson J., Hockey J., 2001, Runners' Tales: Autoethnography, injury and narrative, Auto/Biography, 9.

Anderson L., 2014, Autoetnografia analityczna, Przegląd Socjologii Jakościowej, 10(3).

Bielecka-Prus J., 2012, Normana K. Denzina projekt etnografii interpretacyjnej [in:] A. Szafrański (red.), Geertz. Dziedzictwo-interpretacje-dylematy, Lublin: Wydawnictwo KUL.

Bielecka-Prus J., 2014, Po co nam autoetnografia? Krytyczna analiza autoetnografii jako metody badawczej, Przegląd Socjologii Jakościowej, 10(3).

Bochner A.P., Ellis C.S., 2006, Communication as autoethnography [in:] G.J. Shepherd, J.S. John, T. Striphas (eds), Communication as...: Perspectives on theory, Thousand Oaks, CA: Sage Publications.

Bourdieu P., Passeron J.C., 1990, Reprodukacja. Elementy teorii systemu nauczania, tłum. E. Neyman, Warszawa: Państwowe Wydawnictwo Naukowe.

Chang H., 2008, Autoethnography as method, Walnut Creek, CA: Left Coast Press.

Ciechowska M., Szymańska M., 2017, Wybrane metody jakościowe w badaniach pedagogicznych, cz. 1, Kraków: Wydawnictwo Akademii Ignatianum.

Coser L.A., 2009, Funkcje konfliktu społecznego, tłum. S. Burdziej, Kraków: Zakład Wydawniczy Nomos.

Denzin N.K., 1989, Interpretive Biography, London: Sage.

Denzin N.K., 1997, Interpretative Ethnography, London: Sage.

Denzin N., 2000, Aesthetics and Qualitative inquiry, Qualitative Inquiry, 6(2).

Denzin N.K., 2018, Performance Autoethnography Critical Pedagogy and the Politics of Culture, London: Routledge.

Denzin N.K., Lincoln Y.S., 2005, Handbook of Qualitative Research, Thousand Oaks, CA: Sage Publications.

Doloriert C., Sambrook S., 2009, Ethical confessions of the "I" of autoethnography: The student's dilemma, Qualitative Research in Organizations and Management, 4(1).

Doloriert C., Sambrook S., 2011, Accommodating an autoethnographic PhD: The tale of the thesis, the viva voce and the traditional Business School, Journal of Contemporary Ethnography, 40(5).

Ellis, C., 2004, The Ethnographic I: A Methodological Novel about Autoethnography, Walnut Creek, California: Altamira Press.

Ellis C., 2009, Autoethnography as method (review), Biography, 32(2).

Ellis C., Bochner A., 2000, Autoethnography, Personal Narrative, and Reflexivity: Researcher as Subject [in:] N.K. Denzin, Y.S. Lincoln (eds), Handbook of Qualitative Research, Thousand Oaks, CA: Sage Publications.

Hayano D., 1979, Auto-ethnography: Paradigms, problems and prospects, Human Organization, 38(1).

Holman Jones S., 2005, Autoethnography: Making the personal political [in:] N.K. Denzin, Y.S. Lincoln (eds), Handbook of Qualitative Research, Thousand Oaks, CA: Sage Publications. 
Jakubowska H., 2017, Intymistyczny charakter autoetnografii na przykładzie badań sportowych doświadczeń, Autobiografia. Literatura. Kultura. Media, 2.

Kacperczyk A., 2014a, Autoetnografia - technika, metoda, nowy paradygmat?: o metodologicznym statusie autoetnografii, Przegląd Socjologii Jakościowej, 10(3).

Kacperczyk A, 2014b, Od redaktora: Autoetnografia - w stronę humanizacji nauki, Przeglą Socjologii Jakościowej, 10(3).

Kafar M., 2010, O przełomie autoetnograficznym w humanistyce. W stronę nowego paradygmatu [in:] B. Płonka-Syroka, M. Skrzypek (red.), Doświadczanie choroby w perspektywie badań interdyscyplinarnych, Wrocław: Akademia Medyczna im. Piastów Śląskich.

Kamińska M., 2014, Autoetnografia jako technika badań etnograficznych w Internecie, Przegląd Socjologii Jakościowej, 10(3).

Kępa E., 2012, Autoetnografia - metoda dla odważnych? [w:] K. Citko, M. Morozewicz (red.), Autobiografizm w kulturze współczesnej, Białystok: Trans Humana.

Kępa E., 2014, Autoetnografia nie wzięła się znikąd - rozważania o ciągłości i zmianie, Pareza, 1.

Koczanowicz L., 2015, Polityka dialogu. Demokracja niekonsensualna i wspólnota krytyczna, tlum. K. Liszka, Warszawa: Wydawnictwo Naukowe PWN.

Mendel M., 2000, Partnerstwo rodziny, szkoły i gminy, Toruń: Wydawnictwo Adam Marszałek.

Mendel M., 2017, Pedagogika miejsca wspólnego: miasto i szkoła, Gdańsk: Wydawnictwo Naukowe Katedra.

Maréchal G., 2010, Autoethnography [in:] A.J. Mills, G. Durepos, E. Wiebe (eds), Encyclopedia of case study research, vol. 2, Thousand Oaks, CA: Sage Publications.

Neumann M., 1996, Collecting Ourselves at the End of the Century [in:] C. Ellis, A.P. Bochner, (eds), Composing Ethnography: Alternative Forms of Qualitative Writing, Walnut Creek, CA: Alta-Mira Press.

Olubiński A., 2015, Konflikt jako sytuacja wychowawcza [in:] D. Borecka-Biernat, M. Cywińska (red.), Konflikt społeczny w perspektywie socjologicznej i pedagogiczno-psychologicznej, Warszawa: Difin.

Pilas M., 2020a, Wyobrażenie szkoły w sytuacji konfliktu jako przestrzeni demokratycznej wspólności. Perspektywa demokracji niekonsensualnej [in:] R. Włodarczyk (red.), Utopia a edukacja, t. 4: Dysonanse, kontrasty i harmonie wyobrażeń świata możliwego, Wrocław: Instytut Pedagogiki Uniwersytetu Wrocławskiego.

Pilas M., 2020b, Widmontologiczne ujęcie kategorii wstydowiny a syndrom Dorosłych Dzieci Alkoholików [in:] M. Mendel (red.), Eduwidma. Rzeczy i miejsca nawiedzone, Gdańsk: Wydawnictwo Uniwersytetu Gdańskiego.

Polczyk P., 2012, Autoetnografia jako możliwa metoda badawcza, Forum Oświatowe, 2(47).

Rancière J., 1999, Dis-agrement. Politics and Philosophy, transl. J. Rose, Minneapollis-London: University of Minessota Press.

Reed-Danahay D.E., 1997, Introduction [in:] D. Reed-Danahay (ed.), Auto/Ethnography: Rewriting the Self and the Social, Oxford: Berg.

Richardson L., 2000, Evaluating ethnography, Qualitative Inquiry, 6(2).

Richardson L., 2007, Writing: A method of inquiry [in:] N.K. Denzin, Y.S. Lincoln (eds), Handbook of Qualitative Research, Thousand Oaks, CA: Sage Publications.

Sambrook S., Herrmann A.F., 2018, Organisational autoethnography: possibilities, politics and pitfalls, Journal of Organizational Ethnography, 7. 
Sparkes A.C., 2000, Autoethnography and narratives of self: Reflections on criteria in action, Sociology of Sport Journal, 17.

Śliwerski B., 2007, Pedagogika dziecka. Studium pajdocentryzmu, Gdańsk: Gdańskie Wydawnictwo Psychologiczne.

Urbańska S., 2012, Autoetnografia [in:] K.T. Konecki, P. Chomczyński, Słownik socjologii jakościowej, Warszawa: Difin.

Van Maanen J., 1988, Tales of the Field: On Writing Ethnography, Chicago: University of Chicago Press.

Wajszczyk K., 2015, Konflikt w szkole. Studium etnograficzne, Gdańsk: Wydawnictwo Uniwersytetu Gdańskiego.

Włodarczyk R., 2017, Demokracja, utopia, wychowanie [in:] K. Rejman, R. Włodarczyk (red.), Utopia a edukacja, t. 3: Nadzieja i rozczarowania wyobrażeniami świata możliwego, Wrocław: Instytut Pedagogiki Uniwersytetu Wrocławskiego.

Zawadzki M., 2015, Autoetnografia [in:] M. Kostera (red.), Metody badawcze w zarzadzaniu humanistycznym, Warszawa: Sedno.

\section{Summary}

The article presents an analysis of four school conflicts. I am trying to prove that the teacher-parental conflict is always actively involved with the student, with his paidocentric position in the family, subjectivity and authority as the third party in the process of democratic dialogue. I use the autoethnography method, the most appropriate from my point of view, based on a subjective approach, the analysis of feelings and reactions, self-observation, first-person narrative, analysis of the researcher's notes and own narratives, forcing the full participant in the studied environment (complete member researcher), analytical reflexivity, data transcending. The school in my article is perceived as a place of conflict which is an unobvious expression of democratic dissent and a difficult way of achieving commonality, which is a condition of democracy. The conflict is an indispensable social element and the basis of relations of subjective character, characteristic of democratic forms of social life. Confronting this with knowledge developed around the idea of non-consensual democracy, which is based on discord (dissensus) after the reading. I assume that not only the occurrence of conflicts is a problem, but the lack of orientation on the positive meaning of the situation of disagreement and attitudes related to attaining it and ensuring equality for others in the practice of dialoging participants in school life.

Keywords

conflict, school, subjectivity, non-consensual democracy, autoetnography 